\title{
PERBANDINGAN SLM DAN DBM UNTUK MENGANALISA PENYUSUTAN NILAI PERALATAN LABORATORIUM KOMPUTER UNIVERSITAS ABDURRAB
}

\author{
${ }^{1)}$ Dona Rahmat Putra, ${ }^{2)}$ Wita Yulianti, ${ }^{3)}$ Diki Arisandi \\ 1),2),3) Teknik Informatika, Fakultas Teknik, Universitas Abdurrab \\ Jl. Riau Ujung No. 73 Pekanbaru \\ E-Mail :donnrahmatputra@gmail.com,wita@univrab.ac.id,diki@univrab.ac.id
}

\begin{abstract}
ABSTRAK
Universitas Abdurrab, sebagai salah satu instansi pendidikan di Riau yang memiliki laboratorium komputer yang terdiri dari peralatan komputer dan jaringan lokal. Peralatan komputer dan jaringan yang ada memiliki masa ekonomis, serta setiap tahunnya akan terjadi depresiasi atau penurunan nilai aset. Tujuan dari penelitian ini adalah untuk mengetahui penyusutan peralatan laboratorium komputer, menganalisa penyusutan nilai peralatan komputer dengan membandingkan metode penyusutan, merancang sistem yang sedang berjalan dan memberikan gambaran, masukan serta rekomendasi tentang penggunaan metode penyusutan. Metode penyusutan yang dikomparasikan dalam penelitian ini adalah straight line method dan declining balance method. Metode penyusutan straight line method mengestimasi biaya penyusutan aktiva selalu sama setiap tahunnya, sedangkan declining balance method mengestimasi biaya penyusutan pertahun aktiva cenderung menurun. Kesimpulan dari komparasi kedua motede penyusutan ini yaitu aktiva yang tidak memiliki nilai residu lebih sesuai menggunakan straight line method, sementara aktiva yang memiliki nilai residu dan aktiva yang tergantung pada volume produk lebih sesuai menggunakan declining balance method.
\end{abstract}

Kata Kunci: depresiasi, komparasi, straight line method, declining balance method

\section{ABSTRACT}

Abdurrab University, as one of the educational institutions in Riau which has a computer laboratory consisting of computer equipment and local networks. Existing computer equipment and networks have an economic life, and each year there will be depreciation or impairment of assets. The purpose of this study was to determine the depreciation of computer laboratory equipment, analyze the depreciation of the value of computer equipment by comparing depreciation methods, designing a system that is running and provide an overview, input and recommendations on the use of depreciation methods. The depreciation method compared in this study is the straight line method and declining balance method. The depreciation method of straight line method estimated the depreciation cost of assets is always the same every year, while declining balance method estimated the annual depreciation cost of assets tends to decrease. The conclusion of the both comparison is that these assets which have no residual value are more suitable use a straight line method, while assets that have residual values and assets that depend on product volume are more appropriate use the declining balance method.

Keywords: depreciation, comparison, straight line method, declining balance method

\section{PENDAHULUAN}

Laboratorium komputer di suatu institusi pendidikan yang memiliki jurusan atau disiplin ilmu komputer mutlak diperlukan untuk menunjang pembelajaran dan praktikum (Lei \& Gupta, 2010). Laboratorium komputer yang baik adalah laboratorium yang memiliki peralatan yang lengkap dan memadai (Hariyanto, 2016). Namun untuk memenuhi kebutuhan suatu laboratorium komputer dapat disesuaikan dengan kebijakan suatu institusi pendidikan (Permana, 2014).

Universitas Abdurrab Pekanbaru merupakan salah satu universitas yang memiliki jurusan atau disiplin ilmu komputer. Untuk menunjang pembelajaran yang berhubungan dengan komputer, Universitas Abdurrab mempunyai empat laboratorium komputer, yang terdiri dari laboratorium multimedia, laboratorium jaringan, laboratorium sistem cerdas dan laboratorium CBT (Computer-Based Test).

Berdasarkan sistem yang berjalan Universitas Abdurrab melalui bagian sarana dan prasarana belum memiliki skenario penghitungan penyusutan peralatan laboratorium komputer dengan metode penyusutan. Akibat dari tidak adanya penggunaan metode penyusutan ini, 
bagian sarana dan prasarana Universitas Abdurrab masih menerapkan sistem manual untuk menghitung penyusutan peralatan laboratorium komputer yang ada.

Sebuah peralatan komputer dan jaringan, seiring dengan perkembangan zaman akan mengalami penyusutan atau depresiasi (Safrizal \& Lili, 2015). Penyusutan adalah alokasi sistematis jumlah yang dapat disusutkan dari suatu aset selama umur manfaatnya (Windariyani, 2013).

Menurut Erpina (2016), untuk menghitung biaya penyusutan yang terjadi maka dalam hal ini digunakan yang namanya metode penghitungan penyusutan yaitu: Metode garis lurus (Straight line method), Metode saldo menurun (Declining balance method), Metode jumlah angka tahun (Sum of years digit method), Metode jam jasa (Service hours method), Metode hasil produksi (Productive output method).

Akan tetapi, tidak semua metode penyusutan dapat digunakan untuk menghitung biaya penyusutan aset tetap. Metode penghitungan penyusutan aset tetap yang diperbolehkan menurut PSAK No. 16 Revisi 2011 (Ikatan Akuntan Indonesia, 2011) dan perpajakan itu berbeda. Berdasarkan standar akuntansi yang boleh diterapkan adalah metode garis lurus (straight line method), Metode saldo menurun (declining balance method), Metode jumlah angka tahun (sum of years digit method). Akan tetapi, menurut aturan Perpajakan UndangUndang Perpajakan No. 36 Tahun 2008 tentang pajak penghasilan pasal 11 metode perhitungan penyusutan hanya metode garis lurus (straight line method), metode saldo menurun (declining balance method).

Metode apapun yang dipilih, konsistensi dalam penggunaannya adalah perlu, tanpa memandang tingkat profitabilitas perusahaan, standar akuntansi dan pertimbangan perpajakan, agar dapat menyediakan daya banding hasil operasi perusahaan dari periode ke periode. Dalam hal ini penulis membandingkan straight line method dan declining balance method untuk menganalisa penyusutan nilai peralatan komputer Universitas Abdurrab.

Metode garis lurus (straight line method) ini, menganggap aktiva tetap akan memberikan kontribusi yang merata di sepanjang masa penggunaaanya. Sementara metode saldo menurun (declining balance method) menganggap aktiva tetap memberikan kontribusi yang menurun dengan menggunakan tingkat penyusutan yang selalu tetap dan diaplikasikan untuk mengurangi nilai buku pada setiap akhir tahun. Membandingkan straight line method dan declining balance method diharapkan dapat menjadi solusi alternatif bagi Universitas Abdurrab melalui bagian sarana dan prasarana dalam hal kebijakan manajemen aset terutama peralatan laboratorium komputer.

\section{Beberapa Peralatan Komputer}

Komputer yang ada pada laboratorium komputer umumnya berjenis desktop, yang terdiri dari beberapa peralatan terpisah dan memiliki kegunaan, diantaranya (Sutabri, 2014):

1. Monitor

Monitor sering disebut juga sebagai layar tampilan komputer. Komponen ini sangat familiar karena antarmuka antara komputer dengan pengguna adalah melalui monitor

2. Mouse

Mouse merupakan peranti penunjuk yang digunakan untuk memasukkan data ke dalam komputer. Mouse digunakan sebagai interface titik dan click.

3. Keyboard

Keyboard merupakan perangkat masukan data yang dapat dipakai mengubah huruf, angka, ataupun kode lain menjadi isyarat listrik yang dapat diproses komputer.

4. Chasis Computer

Chasis Computer atau sering juga disebut casing adalah wadah yang menampung komponen-komponen komputer seperti: processor (CPU), motherboard, harddisk dan peranti-peranti yang lainnya (TIM EMS, 2014).

\section{Beberapa Peralatan Jaringan}

Peralatan jaringan yang dibahas adalah peralatan jaringan yang digunakan untuk membuat jaringan lokal dengan kabel, diantaranya (Diat \& Riyanto, 2010): 
1. Kabel UTP

Kabel UTP (Unshielded Twisted Pair) adalah suatu jenis kabel yang paling banyak dipakai untuk membuat jaringan komputer, berupa kabel yang di bagian dalamnya berisikan 4 pasang kabel.

2. Konektor RJ45

Konektor RJ (registered jack) 45 adalah penghubung atau konektor kabel UTP (unshielded twisted pair) yang digunakan dalam jaringan.

3. Hub dan Switch

$H u b$ adalah piranti untuk pembuatan jaringan star yang paling lazim digunakan selain switch. Hub berfungsi sebagai piranti sentral untuk menghubungkan semua komputer di LAN. Switch adalah perangkat jaringan komputer yang berfungsi sebagai konektor / penghubung. Dilihat dari fungsinya, terlihat mirip dengan $h u b$. Perbedaan kedua alat ini adalah soal besaran luas jaringan yang dapat dikerjakan dan besaran transfer data. Switch memiliki cakupan luas jaringan yang lebih besar dari hub, dan switch juga memiliki kecepatan yang lebih tinggi dibanding $h u b$.

\section{Aktiva}

Menurut Ikatan Akuntansi Indonesia (2009), Aktiva adalah sumber daya yang dikuasai entitas sebagai akibat dari peristiwa masa lalu dan dari mana manfaat ekonomi di masa depan diharapkan akan diperoleh entitas. Manfaat ekonomi masa depan yang terwujud dalam aset tersebut untuk memberikan sumbangan, baik langsung maupun tidak langsung, terhadap aliran kas dan setara kas kepada entitas.

\section{Aktiva Tetap}

Menurut Donald et al (2008), Aktiva tetap adalah bagian dari neraca yang dilaporkan oleh manajemen dalam setiap periode atau setiap tahun. Aktiva ini digolongkan menjadi aktiva tetap berwujud dan aktiva tetap tidak berwujud.

1. Aktiva tetap berwujud (tangible fixed assets)
Merupakan harta berwujud yang bersifat jangka panjang dalam aktivitas operasi perusahaan, didalamnya meliputi; tanah, bangunan, perabot, mesin-mesin, dan peralatan lain yang digunakan untuk menghasilkan atau memudahkan penjualan barang dan jasa.

2. Aktiva tetap tidak berwujud (intangible fixed assets)

Aktiva ini tidak dapat diobservasi atau dilihat secara langsung, didalamnya berbentuk persetujuan, kontrak, atau paten, tetapi harta itu sendiri tidak memiliki eksistensi fisik. Harta tak berwujud termasuk pos-pos seperti hak cipta, paten, goodwill, dan perjanjian monopoli.

\section{Penyusutan (Depreciation)}

Penyusutan (depreciation) didefinisikan sebagai proses akuntansi dalam mengalokasikan biaya aktiva berwujud ke beban dengan cara yang sistematis dan rasional selama periode yang diharapkan mendapat manfaat dari penggunaan aktiva tersebut.

Menurut Anita et al (2011), ada tiga faktor yang perlu dipertimbangkan dalam menentukan beban penyusutan setiap periode yaitu:

1. Harga perolehan (cost) yaitu uang yang dikeluarkan atau hutang yang timbul dan biaya-biaya lain yang terjadi dalam perolehan aktiva sampai dengan aktiva siap untuk digunakan.

2. Nilai sisa (salvage value) yaitu jumlah yang diterima bila aktiva itu dijual, ditukarkan atau cara-cara lain untuk aktiva tersebut sudah tidak dapat dipergunakan lagi dikurangi dengan biaya-biaya yang terjadi pada saat penjualan atau pertukaran.

3. Taksiran umur kegunaan (usefull life) yaitu kegunaan suatu aktiva yang dipengaruhi oleh cara-cara pemeliharaan dan kebijaksanaan yang dianut dalam penyusutan. Taksiran masa manfaat ini bisa dinyatakan dalam satuan periode waktu, satuan hasil produksi atau satuan jam kerjanya. 


\section{Straight Line Method (Metode Garis Lurus)}

Metode garis lurus mempertimbangkan penyusutan sebagai fungsi dari waktu, bukan fungsi dari penggunaan. Metode ini paling banyak diterapkan oleh perusahaan-perusahaan karena paling mudah diaplikasikan dalam akuntansi. Dalam metode penyusutan garis lurus, beban penyusutan untuk tiap tahun nilainya sama besar dan tidak dipengaruhi dengan hasil atau output yang diproduksi (Windariyani, 2013). Perhitungan tarif penyusutan untuk metode garis lurus adalah sebagai berikut (Anita et al, 2011):

$$
\text { Metode Garis Lurus }=\frac{\text { Harga Perolehan }- \text { Nilai Sisa }}{\text { Taksiran Umur Kegunaan }}
$$

\section{Declining Balance Method (Metode Saldo Menurun)}

Menurut Donald et al (2009), metode declining balance menggunakan tarif penyusutan (diekspresikan sebagai persentase) berupa beberapa kelipatan dari metode garis lurus. Sebagai contoh, tarif saldo menurun untuk aktiva 10 tahun akan menjadi 20\% (dua kali tarif garis lurus, yaitu $1 / 10$ atau $10 \%$ ). Tarif saldo menurun tetap konstan dan diaplikasikan pada nilai buku yang menurun setiap tahun.

Dalam metode saldo menurun, nilai sisa tidak dikurangkan dalam menghitung dasar penyusutan. Tarif saldo menurun dikalikan dengan nilai buku aktiva pada awal setiap periode. Karena nilai buku aktiva dikurangi setiap periode dengan beban penyusutan, maka tarif saldo menurun yang konstan diaplikasikan pada nilai buku yang terus menerus menurun yang menghasilkan beban penyusutan yang semakin rendah setiap tahunnya. Proses ini terus berlangsung hingga nilai buku aktiva berkurang mencapai estimasi nilai sisanya, dimana pada saat tersebut penyusutan akan dihentikan atau disusutkan sekaligus. Perhitungan tarif penyusutan untuk metode declining balance adalah sebagai berikut (Windariyani, 2013):

Penyusutan $=$ Tarif Penyusutan $x$ (harga perolehan-akumulasi penyusutan)

\section{Estimasi Umur Manfaat}

Didalam penyusutan, untuk estimasi umur manfaat, dihitung berdasarkan ketentuan dari UU PPh No 36 Tahun 2008 Pasal 11 (Kementerian Keuangan republik Indonesia Direktorat Jenderal Pajak, 2013). Adapun ketentuannya dapat dilihat pada tabel berikut:

Tabel 1. Estimasi Umur Manfaat Aktiva

\begin{tabular}{|c|c|c|c|}
\hline \multirow{2}{*}{$\begin{array}{c}\text { Kelompok Harta } \\
\text { Berwujud }\end{array}$} & \multirow{2}{*}{$\begin{array}{l}\text { Masa } \\
\text { Manfaat }\end{array}$} & \multicolumn{2}{|c|}{$\begin{array}{l}\text { Tarif Penyusutan sebagaimana } \\
\text { dimaksud dalam }\end{array}$} \\
\hline & & Ayat (1) & Ayat (2) \\
\hline \multicolumn{4}{|l|}{ I. Bukan bangunan } \\
\hline Kelompok 1 & 4 tahun & $25 \%$ & $50 \%$ \\
\hline Kelompok 2 & 8 tahun & $12,5 \%$ & $25 \%$ \\
\hline Kelompok 3 & 16 tahun & $6,25 \%$ & $12,5 \%$ \\
\hline Kelompok 4 & 20 tahun & $5 \%$ & $10 \%$ \\
\hline \multicolumn{4}{|l|}{ III. Bangunan } \\
\hline Permanen & 20 tahun & $5 \%$ & \\
\hline Tidak Permanen & 10 tahun & $10 \%$ & \\
\hline
\end{tabular}

Dari tabel diatas dapat dijelaskan tentang tarif penyusutan ayat (1) dipergunakan untuk straight line method (metode garis lurus) dan tarif penyusutan ayat (2) dipergunakan untuk declining balance method (metode saldo menurun).

\section{Pembagian Jenis Aktiva}

Untuk pembagian setiap kategori untuk tiap kelompoknya sesuai dengan Peraturan Menteri Keuangan Nomor 96/PMK.03/2009 (Keputusan Menteri Keuangan Republik Indonesia, 2009) dapat dilihat pada tabel berikut:

Tabel 2. Pembagian Jenis Aktiva Berdasarkan Kelompok

\begin{tabular}{|c|c|c|}
\hline No & Kelompok & Contoh Jenis Barang / Harta \\
\hline 1 & Kelompok 1 & $\begin{array}{l}\text { 1.Mebel dan peralatan dari kayu atau rotan termasuk } \\
\text { meja, bangku, kursi, lemari dan sejenisnya yang bukan } \\
\text { bagian dari bangunan. } \\
\text { 2.Mesin kantor seperti mesin tik, mesin hitung, } \\
\text { duplikator, mesin fotokopi, mesin } \\
\text { akunting/pembukuan, komputer, printer, scanner dan } \\
\text { sejenisnya. } \\
\text { 3.Perlengkapan lainnya seperti amplifier, tape/cassette, } \\
\text { video } \\
\text { 4.recorder, televisi dan sejenisnya. } \\
\text { 5.Sepeda motor, sepeda dan becak. } \\
\text { 6.Alat perlengkapan khusus (tools) bagi industri/jasa yang } \\
\text { 7.bersangkutan. } \\
\text { 8.Alat-alat komunikasi seperti pesawat telepon, faksimile, } \\
\text { telepon seluler dan sejenisnya. }\end{array}$ \\
\hline 2 & Kelompok 2 & $\begin{array}{l}\text { 1. Mebel dan peralatan dari logam termasuk meja, bangku, } \\
\text { kursi, lemari dan sejenisnya yang bukan merupakan } \\
\text { bagian dari bangunan. } \\
\text { 2.Alat pengatur udara seperti AC, kipas angin dan } \\
\text { sejenisnya. } \\
\text { 3. Mobil, bus, truk, speed boat dan sejenisnya. } \\
\text { 4.Container dan sejenisnya. }\end{array}$ \\
\hline 3 & Kelompok 3 & $\begin{array}{l}\text { Mesin-mesin yang dipakai dalam bidang pertambangan, } \\
\text { termasuk mesin-mesin yang mengolah produk pelikan. }\end{array}$ \\
\hline 4 & Kelompok 4 & $\begin{array}{l}\text { 1.Lokomotif uap dan tender atas rel. } \\
\text { 2.Lokomotif listrik atas rel, dijalankan dengan batere atau } \\
\text { dengan tenaga listrik dari sumber luar. } \\
\text { 3.Kereta, gerbong penumpang dan barang, termasuk } \\
\text { kontainer khusus dibuat dan diperlengkapi untuk ditarik } \\
\text { dengan satu alat atau beberapa alat pengangkutan. } \\
\text { 4.Kapal penumpang, kapal barang, kapal khusus dibuat } \\
\text { untuk pengangkutan barang-barang tertentu (misalnya } \\
\text { gandum, batu-batuan, biji tambang dan sejenisnya) } \\
\text { termasuk kapal pendingin dan kapal tangki, kapal } \\
\text { penangkap ikan dan sejenisnya, yang mempunyai berat } \\
\text { di atas } 1.000 \text { DWT. }\end{array}$ \\
\hline
\end{tabular}




\section{METODE}

\section{Tempat Penelitian}

Penelitian ini dilakukan di Universitas Abdurrab, dengan meneliti peralatan laboratorium komputer Universitas Abdurrab. Laboratorium Universitas Abdurrab terdiri dari: laboratorium multimedia, laboratorium jaringan, laboratorium sistem cerdas dan laboratorium CBT (Computer Based Test).

\section{Kerangka Penelitian}

Kerangka penelitian merupakan tahapantahapan untuk melakukan suatu penelitian. Adapun tahapan-tahapan dalam kerangka penelitian tersebut adalah sebagai berikut:

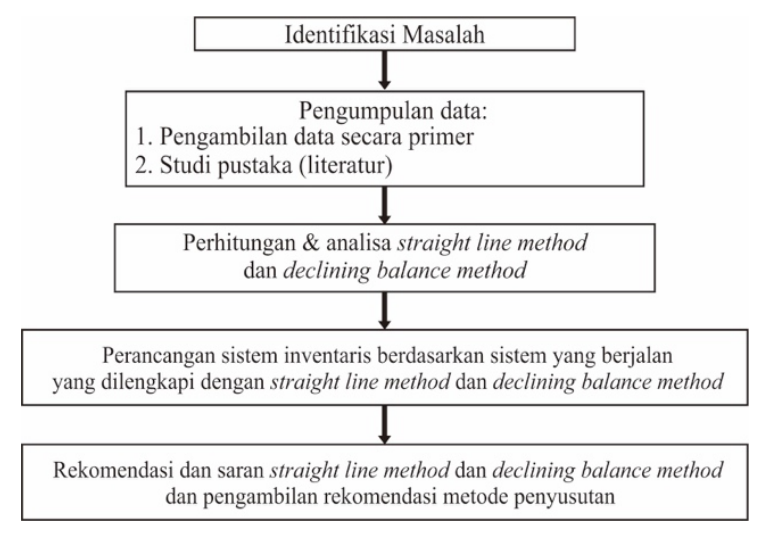

Gambar 1. Kerangka penelitian

\section{Uraian Kerangka Penelitian}

Uraian kerangka penelitian adalah penjelesan mengenai tahapan-tahapan yang dilakukan dalam penelitian. Adapun uraian kerangka penelitian diatas adalah sebagai berikut:

1. Identifikasi Masalah

Tahap pertama dalam kerangka penelitian adalah identifikasi masalah. Adapun Permasalahan dalam penelitian ini adalah belum adanya kebijakan tentang penetapan umur ekonomis dan perhitungan penyusutan manajemen aset terutama yang berhubungan dengan peralatan komputer Universitas Abdurrab.

\section{Pengumpulan Data}

Tahap kedua dalam kerangka penelitian adalah pengumpulan data. Pengumpulan data yang dilakukan penulis adalah dengan cara sebagai berikut: a. Pengambilan data

Penulis melakukan pengumpulan data mengenai inventaris peralatan laboratorium komputer secara primer melalui bagian sarana dan prasarana Universitas Abdurrab.

b. Studi Pustaka (Literatur)

Pengumpulan data dengan cara studi pustaka (literatur) yaitu mengumpulkan data dan informasi referensi mengenai penyusutan, metode penyusutan, peraturan perundangan-undangan yang terkait.

3. Perhitungan Menggunakan SLM dan DBM

Tahap ketiga dalam kerangka penelitian ini adalah menghitung besaran penyusutan pertahun peralatan laboratorium komputer Universitas Abdurrab.

Dalam perhitungan ini penulis menggunakan straight line method dan declining balance method.

Berikut contoh perhitungan penyusutan dengan straight line method (metode garis lurus):

a. Sebuah barang A dibeli seharga Rp 5.000.000 pada awal tahun 2014, nilai residu barang ini adalah $\mathrm{Rp}$ 0. Jika barang ini termasuk barang kelompok 1 yang mempunyai masa manfaat atau umur ekonomis empat tahun dan akumulasi penyusutan pertahunnya adalah $25 \%$, maka perhitungannya dapat dilihat pada Tabel 3.

Tabel 3. Perhitungan Penyusutan Menggunakan SLM

\begin{tabular}{|c|c|c|c|c|}
\hline Tahun & $\begin{array}{c}\text { Harga } \\
\text { Perolehan }\end{array}$ & $\begin{array}{c}\% \\
\text { Penyusutan }\end{array}$ & $\begin{array}{c}\text { Biaya } \\
\text { Penyusutan }\end{array}$ & $\begin{array}{c}\text { Nilai Sisa } \\
\text { Buku }\end{array}$ \\
\hline 2014 & 5.000 .000 & $25 \%$ & 1.250 .000 & 3750000 \\
\hline 2015 & & $25 \%$ & 1.250 .000 & 2500000 \\
\hline 2016 & & $25 \%$ & 1.250 .000 & 1250000 \\
\hline 2017 & & $25 \%$ & 1.250 .000 & 0 \\
\hline 2018 & & $25 \%$ & 1.250 .000 & -1250000 \\
\hline
\end{tabular}

Berdasarkan tabel 1 diatas dapat dijelaskan bahwa biaya penyusutan dengan menggunakan straight line method cenderung konstan (tetap) setiap tahunnya, yaitu Rp. 1.250.000 dan aktiva 
tersebut akan habis masa ekonomisnya pada tahun 2017, artinya pada tahun ini aktiva tersebut sudah melebihi masa pakai. Dari besaran biaya penyusutan tersebut maka nilai ekonomis barang akan berkurang dengan akumulasi sebesar biaya penyusutan pertahun. Akumulasi biaya penyusutan pertahun dipergunakan sebagai biaya perawatan, perbaikan atau sebagai simpanan alokasi dana yang dapat dipergunakan pada saat umur ekonomis barang sudah habis (Fachruddin, 2013).

Sedangkan Perhitungan tarif penyusutan untuk declining balance method adalah sebagai berikut:

b. Sebuah barang A dibeli seharga Rp 5.000.000 pada awal tahun 2014, nilai residu barang ini adalah Rp 0. Jika barang ini termasuk barang kelompok 1 yang mempunyai masa manfaat atau umur ekonomis empat tahun dan akumulasi penyusutan pertahunnya adalah $50 \%$, maka perhitungannya dapat dilihat pada Tabel 4

Tabel 4. Perhitungan Penyusutan Menggunakan DBM

\begin{tabular}{|c|c|c|c|c|}
\hline Tahun & $\begin{array}{c}\text { Harga } \\
\text { Perolehan }\end{array}$ & $\begin{array}{c}\% \\
\text { Penyusutan }\end{array}$ & $\begin{array}{c}\text { Biaya } \\
\text { Penyusutan }\end{array}$ & $\begin{array}{c}\text { Nilai Sisa } \\
\text { Buku }\end{array}$ \\
\hline 2014 & 5000000 & $50 \%$ & 2500000 & 2500000 \\
\hline 2015 & & $50 \%$ & 1250000 & 1250000 \\
\hline 2016 & & $50 \%$ & 625000 & 625000 \\
\hline 2017 & & $50 \%$ & 312500 & 312500 \\
\hline 2018 & & $50 \%$ & 156250 & 156250 \\
\hline
\end{tabular}

Berdasarkan tabel 2 diatas dapat dijelaskan bahwa biaya penyusutan dengan menggunakan declining balance method pada awal tahun cenderung lebih tinggi dibandingkan tahun-tahun berikutnya. Karena declining balance method ini memperbolehkan pembebanan yang lebih tinggi pada tahun-tahun awal dibanding metode garis lurus, sehingga sering disebut metode penyusutan dipercepat (accelerated depreciation methods) (Donald et al, 2008). Proses ini terus berlangsung hingga nilai sisa buku aktiva tersebut berkurang mencapai estimasi nilai sisanya, dimana pada saat tersebut penyusutan akan dihentikan atau dengan kata lain disusutkan sekaligus (Franstia, 2016).

\section{Analisa Perbandingan SLM Dan DBM}

Tahap keempat dalam kerangka penelitian ini adalah analisa perbandingan straight line method dan declining balance method. Tahapan analisa disini adalah tahapan yang dilakukan setelah melakukan perhitungan penyusutan nilai peralatan komputer dengan kedua metode tersebut. Selanjutnya membandingkan besaran penyusutan dari metode tersebut.

Dari sampel diatas dapat dilakukan analisa perbandingan straight line method dan declining balance method sebagai berikut:

Tabel 5. Analisa Awal Penyusutan SLM dan DBM

\begin{tabular}{|c|c|}
\hline Metode Penyusutan & Beban Penyusutan Tahun Berjalan \\
\hline Straight Line & Cenderung konstan \\
\hline Declining Balance & Lebih tinggi di awal tahun \\
\hline
\end{tabular}

Berdasarkan tabel diatas dapat dijelaskan bahwa penggunaan metode penyusutan straight line method untuk beban penyusutan tahun berjalan cenderung lebih konstan dari periode ke periode. Sedangkan metode penyusutan declining balance method biaya penyusutan cenderung lebih tinggi pada tahun-tahun awal dan beban yang lebih rendah pada periode mendatang.

4. Pengambilan Rekomendasi dan Saran

Tahap terakhir dalam kerangka penelitian ini adalah tahapan pengambilan rekomendasi dan saran. Tahap ini dilakukan setelah melakukan tahapan-tahapan sebelumnya. Adapun pengambilan rekomendasi dan saran yang penulis lakukan adalah dengan membuat grafik perbandingan kedua metode penyusutan tersebut:

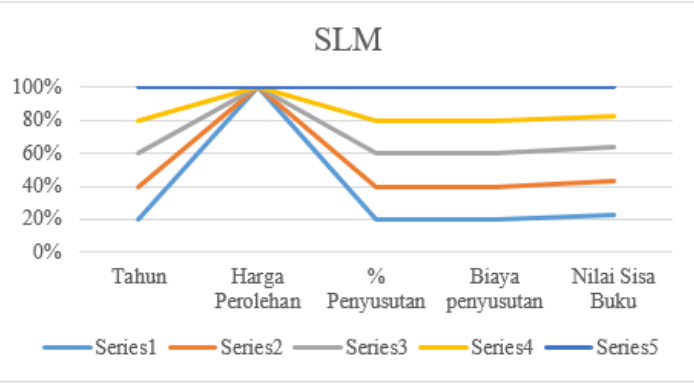

Gambar 2. Grafik SLM 


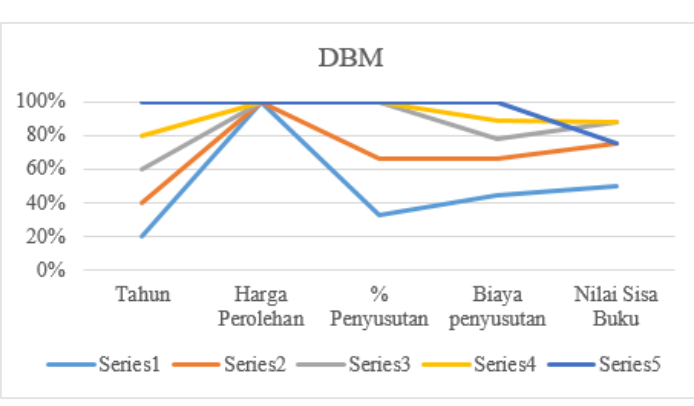

Gambar 3. Grafik DBM

Dari kedua gambar grafik diatas dapat dijelaskan perbedaan kedua metode tersebut. Straight line method (metode garis lurus) menunjukan grafik data yang konstan, sedangkan declining balance method (metode saldo menurun) menunjukan grafik data yang cenderung tinggi diawal dan menurun diakhir penyusutan. Selanjutnya metode mana yang baik dan cocok untuk digunakan dalam hal manajemen aset, terutama yang berhubungan dengan peralatan komputer dan jaringan.

Hasil dari kesimpulan tersebut dapat menjadi rekomendasi pihak Universitas Abdurrab melalui bagian sarana dan prasarana agar dijadikan suatu kebijakan mengenai manajemen aset dalam hal penyusutan.

\section{HASIL}

\section{Analisa Perbandingan SLM dan DBM}

Adapun analisa dari perhitungan inventaris laboratorium komputer dengan straight line method dan declining balance method dijelaskan pada tabel berikut ini:

Tabel 6. Analisa Perbandingan SLM dan DBM

\begin{tabular}{|c|c|c|c|}
\hline $\begin{array}{c}\text { Metode } \\
\text { Penyusutan }\end{array}$ & Penerapan Aktiva Lab & $\begin{array}{c}\text { Biaya } \\
\text { Penyusutan }\end{array}$ & $\begin{array}{c}\text { Aktiva dengan } \\
\text { Nilai Residu }\end{array}$ \\
\hline SLM & $\begin{array}{c}\text { 21 Aktiva (Hub, Kursi, } \\
\text { Meja Komputer, } \\
\text { Whiteboard, Projector, } \\
\text { UPS) }\end{array}$ & sama besar & Kurang sesuai \\
\hline DBM & $\begin{array}{c}\text { 12 Aktiva (Komputer PC, } \\
\text { AC, Stabilizer) }\end{array}$ & $\begin{array}{c}\text { terus } \\
\text { menurun }\end{array}$ & Sesuai \\
\hline
\end{tabular}

Berdasarkan tabel diatas dapat dilihat bahwa analisa perbandingan straight line method dan declining balance method dilihat dari beberapa aspek diantaranya pengaplikasian aktiva, biaya penyusutan dan nilai residu.

Aktiva yang memberikan kontribusi terbesar pada masa awal penggunaanya, seperti komputer, stabilizer dan AC, lebih sesuai menggunakan declining balance method, karena metode ini menganggap biaya penyusutan aktiva pertahun selalu menurun sehingga nilai sisa buku aktiva tersebut ikut berkurang sebesar akumulasi biaya penyusutan pertahun aktiva tersebut. Dengan kata lain, penerapan metode DBM lebih sesuai ke aktiva yang tingkat kehausannya tergantung dari volume produk yang dihasilkan (Nicho, 2014).

Sementara, aktiva yang tidak memiliki nilai residu selama masa manfaatnya, seperti: $h u b$, meja, projector lebih sesuai menggunakan straight line method, karena metode ini menganggap memberikan kontribusi yang merata di sepanjang masa penggunaannya yaitu biaya penyusutan yang sama besar. Besaran biaya penyusutan yang dihasilkan dengan metode SLM memperkirakan sisa nilai buku sesuai dengan perkiraan metode SLM yaitu 4 tahun masa ekonomisnya, dimana untuk peralatan komputer masa manfaatnya adalah 4 tahun (Franstia, 2016).

\section{Perancangan Sistem}

Dalam penelitian ini perancangan sistem berdasarkan sistem yang sedang berjalan terdiri dari gambaran umum sistem, perancangan tabel, dan interface. Adapun perancangan sistem dalam penelitian ini adalah sebagai berikut:

\section{Gambaran Umum Sistem}

Gambaran umum sistem dalam penelitian ini terdiri dari aliran sistem informasi, DFD, dan ERD. Adapun penjelasannya adalah sebagai berikut:

\section{a. Aliran Sistem Informasi}

Adapun aliran sistem informasi yang sedang berjalan saat ini adalah sistem yang sedang dipakai di Universitas Abdurrab melalui bagian sarana dan prasarana. Untuk aliran sistem informasi dapat dilihat pada gambar 4.1 


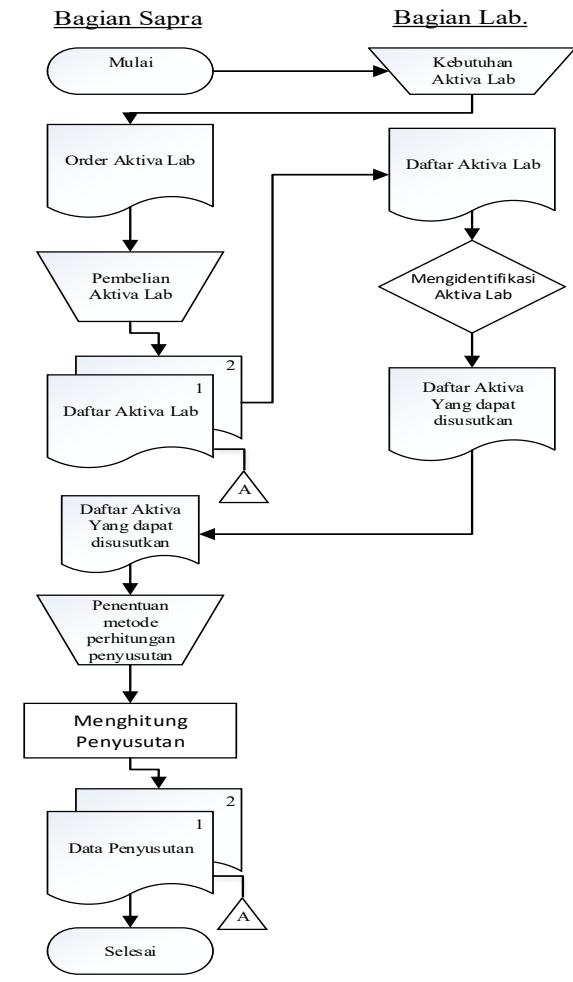

Gambar 4. Aliran Sistem Informasi Berjalan

Pada gambar 4 dijelaskan bahwa bagian laboratorium memberikan daftar kebutuhan aktiva laboratorium kepada bagian sarana dan prasarana Universitas Abdurrab. Selanjutnya bagian sapra melalukan pembelian aktiva sesuai kebutuhan laboratorium. Bagian laboratorium membuat identifikasi aktiva terkait masa pakai aktiva dan selanjutnya kembali diproses bagian sarana dan prasarana Universitas Abdurrab.

Berdasarkan prosedur yang ditunjukan pada gambar 4 maka dilakukan evaluasi sistem yaitu:

a. Untuk perhitungan penyusutan aktiva laboratorium dilakukan oleh bagian sarana dan prasarana dengan menentukan penggunaan metode penyusutan.

b. Penggunaan metode penyusutan akan mempermudah pihak sarana dan prasarana Universitas Abdurrab dalam menentukan masa ekonomis aktiva laboratorium, sehingga dapat melakukan skenario perencanaan dana maintenance dan pergantian peralatan laboratorium yang ada.
Data Flow Diagram (DFD) adalah alat pembuatan model yang memungkinkan profesional sistem untuk menggambarkan sistem sebagai suatu jaringan proses fungsional yang dihubungkan satu sama lain dengan alur data, baik secara manual maupun komputerisasi. Dalam penelitian ini menggunakan DFD level 0 atau context diagram dan DFD level 1.

1. DFD level 0 atau Context Diagram

DFD level 0 atau context diagram merupakan level tertinggi dari suatu Data Flow Diagram (DFD). Diagram konteks memberi gambaran seluruh elemen sistem. Adapun diagram konteks pada penelitian ini adalah sebagai berikut:

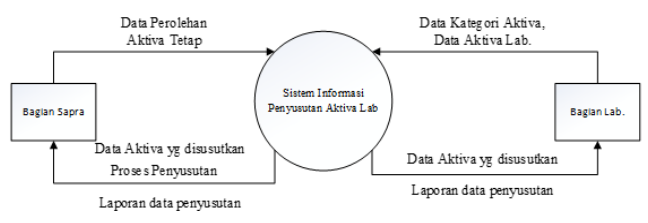

Gambar 5. Context Diagram Informasi Penyusutan Aktiva Lab

2. DFD level 1

DFD level 1 merupakan hasil dekomposisi dari Context Diagram level 0 pada penelitian ini. Adapun DVD level 1 pada penelitian ini adalah sebagai berikut:

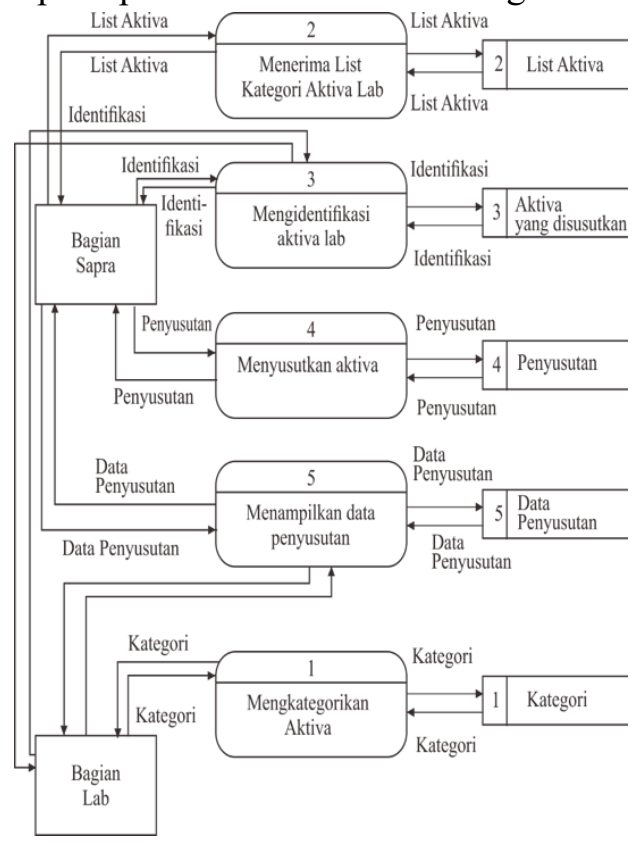

Gambar 6. DFD Level 1 b. DFD 


\section{ERD (Entity Relationship Data)}

ERD disajikan dalam bentuk diagram hubungan entitas. Terdiri dari entitas, atribut, garis penghubung dan relasi. Entity Relationship Diagram adalah suatu model untuk menjelaskan hubungan antar data dalam basis data berdasarkan objek-objek dasar data yang mempunyai hubungan antar relasi.

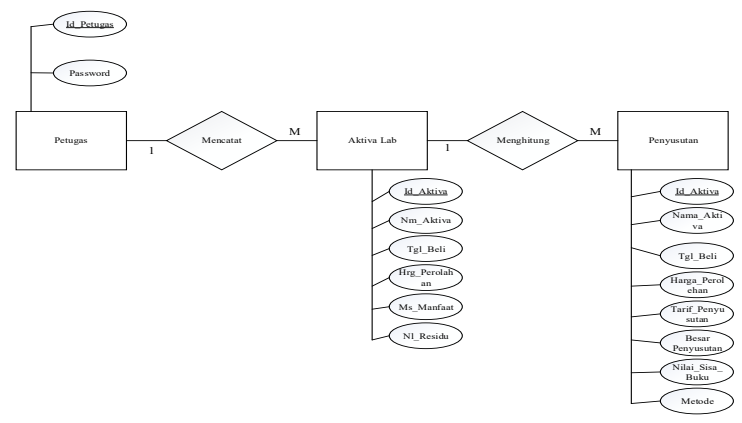

Gambar 7. ERD Penghitungan Penyusutan Aktiva Lab

b. Desain Antar Muka (Interface)

Desain antar muka (interface) merupakan rancangan bentuk tampilan grafis yang berhubungan langsung dengan pengguna (user). Adapun desain antarmuka (interface) pada penelitian ini adalah sebagai berikut:

\section{Tampilan Form Login}

Rancangan form login merupakan rancangan form pertama kali yang muncul jika sistem yang berjalan ini dibuka. Rancangan form login ini terdiri dari user dan password. Adapun rancangan form login ini dapat dilihat pada gambar berikut:

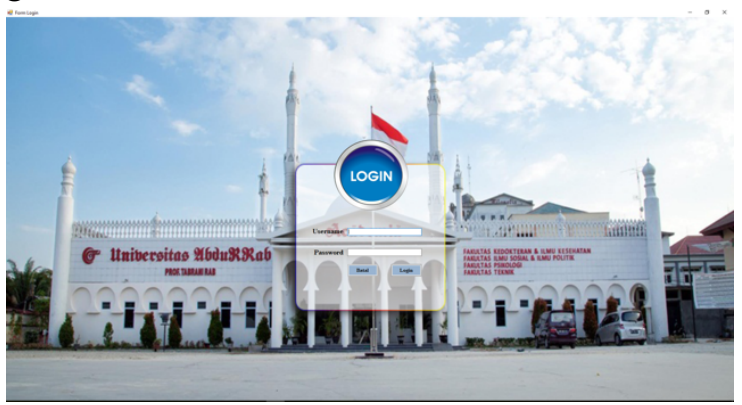

Gambar 8. Tampilan Form Login

\section{Tampilan Menu Utama}

Halaman menu utama merupakan tampilan awal yang digunakan petugas untuk mengakses ke menu berikutnya. Adapun tampilan menu utama sebagai berikut:

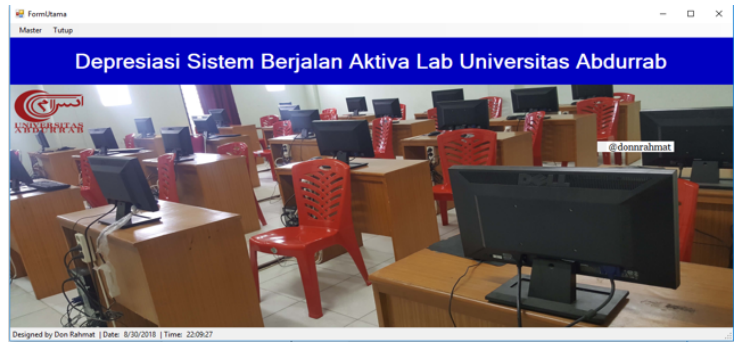

Gambar 10. Tampilan Menu Utama

\section{Tampilan Input Aktiva}

Pada form input aktiva, user memasukan id aktiva, nama aktiva, tanggal beli, harga perolehan, masa manfaat dan nilai residu. Adapaun tampilan input aktiva adalah sebagai berikut:

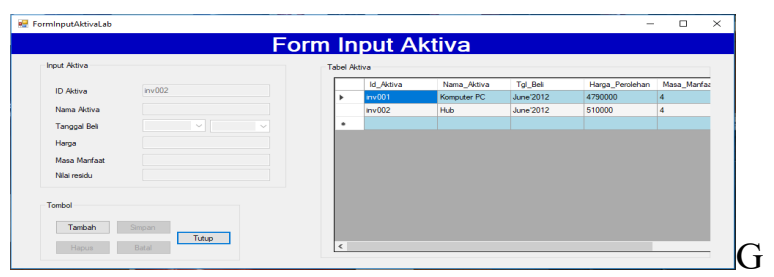

ambar 11. Tampilan Input Aktiva

\section{Tampilan Proses}

Pada form ini akan melakukan perhitungan penyusutan dengan straight line method dan declining balance method. Adapun tampilan form perhitungan penyusutan adalah sebagai berikut:

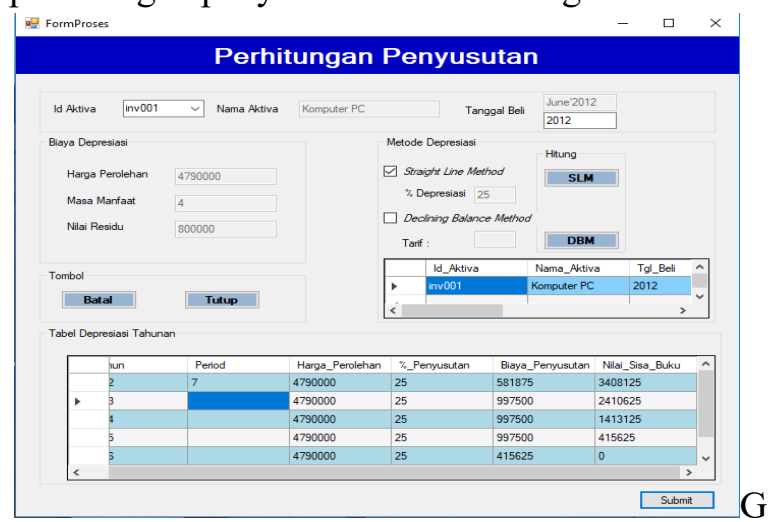

ambar 12. Tampilan Proses Depresiasi

\section{Tampilan Laporan}

Pada menu laporan merupakan form yang menampilkan hasil dari suatu form yang ada untuk melakukan proses cetak. Adapun tampilan form laporan adalah sebagai berikut: 


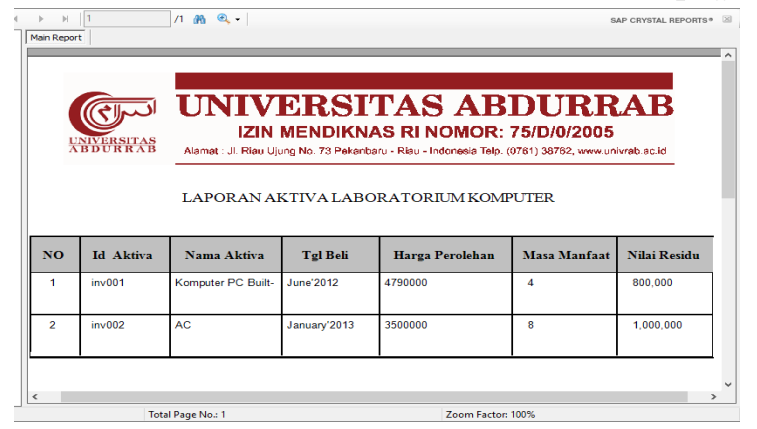

Gambar 13. Tampilan Proses Laporan

\section{Rekomendasi dan Saran}

Pada dasarnya aset tetap akan memberikan kontribusi terbesarnya pada awal-awal masa penggunaannya, karena aktiva dalam kondisi bagus dengan kekuatan yang masih optimal. Namun, seiring berjalannya waktu, kontribusi aset terbesar tersebut mulai menurun, kinerjanya tak lagi maksimal dan turun performa.

Oleh karena itu, berdasarkan dari penghitungan, analisa dan perancangan sistem yang sedang berjalan yang penulis lakukan terhadap peralatan laboratorium komputer Universitas Abdurrab, maka penulis merekomendasikan penggunaan metode penyusutan sangatlah perlu terhadap aktiva tetap karena mempunyai peranan penting bagi institusi pendidikan.

Penggunaan metode penyusutan terhadap aktiva dapat membantu Universitas Abdurrab melalui bagian sarana dan prasarana dalam hal kebijakan manajemen aset, sehingga dapat mengalokasikan dana maintenance peralatan laboratorium komputer yang ada.

Pada bagian laboratorium komputer, dengan adanya kebijakan terhadap manajemen aset akan membantu atau memudahkan kegiatankegiatan operasional civitas academica yang berhubungan dengan komputer diantaranya proses belajar mengajar, praktikum, dan riset.

Metode apapun yang dipilih, konsistensi dalam penggunaannya adalah perlu, tanpa memandang tingkat profitabilitas perusahaan, standar akuntansi dan pertimbangan perpajakan, agar dapat menyediakan daya banding hasil operasi perusahaan dari periode ke periode.

Aktiva laboratorium yang mempunyai nilai sisa dan penggunaannya berdasarkan atau tergantung dari volume produk yang dihasilkan seperti: komputer, AC, dan stabilizer sebaiknya menggunakan metode DBM (declining balance method) karena biaya penyusutannya yang terus menerus menurun sehingga nilai sisa bukunya berkurang sebesar akumulasi biaya penyusutan pertahun dan tidak terikat pada perkiraan ketentuan masa ekonomis aktiva.

Sedangkan aktiva yang tidak mempunyai nilai sisa, seperti: hub, projector, dan UPS lebih baik menggunakan metode SLM (straight line method) karena biaya penyusutan yang sama besar membuat nilai sisa buku akan berkurang sebesar biaya penyusutan sehingga dapat mengestimasi masa ekonomis aktiva lebih efektif (Daemi, 2012).

\section{KESIMPULAN}

Berdasarkan hasil analisa dan pengujian yang dilakukan penulis, maka dapat disimpulkan bahwa:

1. Perhitungan penyusutan inventaris laboratorium komputer Universitas Abdurrab menggunakan metode penyusutan straight line method dan declining balance method. Perhitungan kedua metode ini dilihat dari harga perolehan, nilai residu (sisa) dan taksiran umur kegunaan aktiva.

2. Perbandingan straight line method dan declining balance method terhadap penyusutan inventaris laboratorium komputer Universitas Abdurrab terletak pada jenis kontribusi aktiva laboratorium komputer yang ada. Aktiva seperti furniture dan elektronik yang tidak memiliki nilai residu, lebih sesuai menggunakan straight line method, karena metode SLM mengestimasi biaya penyusutan pertahun aktiva selalu sama, sedangkan aktiva seperti elektronik yang memiliki nilai residu dan tingkat kehausannya tergantung pada produk lebih sesuai menggunakan declining balance method, karena biaya penyusutannya selalu menurun dari tahun ketahun. 
3. Rancangan sistem penyusutan nilai inventaris laboratorium komputer Universitas Abdurrab berdasarkan sistem yang sedang berjalan, dengan membuat gambaran umum sistem, perancangan tabel dan desain interface (antarmuka) kedua metode penyusutan tersebut.

4. Penggunaan metode penyusutan nilai laboratorium komputer Universitas Abdurrab sangatlah perlu, sehingga memudahkan pihak sarana dan prasarana Universitas Abdurrab dalam hal manajemen aset tentang pengalokasian anggaran dana maintenance laboratorium komputer.

\section{DAFTAR PUSTAKA}

[1]. Anita, Andi Suci, dkk. 2011. Analisis Pendapatan Penerima Bantuan Langsung Masyarakat-Pengembangan Usaha Agribisnis Perdesaan ( BLMPUAP) di Kabupaten Barito Kuala. Agribisnis FMIPA, Vol. 1.

[2]. Daemi. dkk. 2012. Penghitungan Penyusutan Aktiva Tetap dengan Metode Garis Lurus Menggunakan Visual Basic 6.0 (Studi Kasus: PT. Samyuan Manunggal Perkasa Cirebon). Online ICT STNUIK IKMI, Vol. 1.

[3]. Erpina, Mia. 2016. Analisis Perbedaan Laba Perusahaan dengan Menggunakan Metode Penyusutan Aset Tetap berdasarkan Standar Akuntansi Keuangan dan Undang-Undang Perpajakan. Jurnal Akuntansi.

[4]. Fachruddin, Muhammad. 2013. Analisis Akuntansi Aset Tetap Pada Hotel Harsa Dumai. Skripsi Ekonomi dan Ilmu Sosial Universitas Islam Negeri Sultan Syarif Kasim Riau.
[5]. Ferdiansyah, Yusuf, dkk. 2014. Sistem Pengendalian Aset Menggunakan Metode Straight Line dan Simple Additive Weighting. Jurnal Sains, Teknologi dan Industri, 11(1693-2390), pp. 259-265.

[6]. Hariyanto, Joko. 2016. Pengelolaan Pengembangan Laboratorium Teknik Komputer Jaringan. Skripsi Administrasi Pendidikan Universitas Muhammadiyah Surakarta.

[7]. Ikatan Akuntansi Indonesia. 2009. Standar Akuntansi Keuangan Entitas tanpa Akuntanbilitas Publik. Jakarta: Dewan Standar Akuntansi Keuangan.

[8]. Kementerian Keuangan republik Indonesia Direktorat Jenderal Pajak. 2013. Undang-Undang PPh dan Peraturan Pelaksanaanya. Jakarta Selatan: Direktur Penyuluhan Pelayanan dan Humas.

[9]. Keputusan Menteri Keuangan Republik Indonesia. 2009. Attachment 1 of the Minister of treasury Regulation number 9 / PMK.03 / 2009 on types of property belonging to the group of tangible property not for the purpose of depreciation. Indonesia, pp. 1-4.

[10].Kieso, Donal E., dkk. 2008. Akuntansi Intermediate. 12 Jilid 1. Jakarta: Penerbit Erlangga.

[11].Lei, S. A., dkk. 2010. Evaluating Benefits and Costs From Institutional, Faculty and Students' Perspectives. College distance education courses, 4(130), pp. 616-632.

[12].Manalu, Esdinar. 2017. Analisa Management Bandwidth Dengan Metode Antrian Hirarchical Token Bucket. Skrispi Teknik Informatika Universitas Abdurrab. 
[13].Mardjani, Ajeng Citralarasati. dkk. 2015. Perhitungan Penyusutan Aset Tetap Menurut Standar Akuntansi Keuangan dan Peraturan Perpajakan Pengaruhnya terhadap Laporan Keuangan Pada PT. Hutama Karya Manado, EMBA, 3(1), pp. 1024-1033.

[14].Murhada, dkk. 2011. Pengantar Teknologi Informasi. Tangerang: Penerbit Mitra Wacana Media.

[15].Nicho, Eka. Declining Balance Method. 2014; http://nichonotes.blogspot.com [diakses 30 Agustus 2018]

[16].Nunulasa. Depresiasi. 2011; http://nunulasa.wordpress.com [diakses 4 Oktober 2018]

[17].Permana, Agus Aan Jiwa. 2014. Pengembangan Lab Komputer Sederhana Berbasis Jaringan Multipoint Menggunakan Switch Sebagai Sarana Penunjang Proses Pembelajaran, Jurnal Nasional Pendidikan Teknik Informatika (JANAPATI), 3(20), pp. 51-57.

[18].Prasojo, Diat, dkk. 2010. Teknologi Informasi Pendidikan. 1st edn. Yogyakarta: Penerbit Gava Media.

[19].Safrizal, dkk. 2015. Rancang Bangun Aplikasi Penyusutan Aktiva Tetap. Jurnal Teknologi Informasi dan Multimedia.

[20].Susilo, Franstia Wira Sukma. 2016. Rancang Bangun Aplikasi Sistem Informasi Manajemen Aset Perusahaan (Studi Kasus : Stikom Surabaya). Jurnal Sistem Informasi, pp. 1-15.

[21].Sutabri, Tata. 2014. Pengantar Teknologi Informasi. 1st edn. Yogyakarta: Penerbit Andi.
[22].TIM EMS. 2014. Panduan Belajar Komputer Untuk Semua Orang. Jakarta: PT Elex Media Komputindo.

[23].Winarno, Ali, dkk. 2014. Membuat Jaringan Komputer di Windows dan Linux. Jakarta: PT Elex Media Komputindo.

[24].Windariyani, Fitrima. 2013. Perlakuan Akuntansi Penyusutan Aktiva Tetap dan Pengaruhnya Terhadap Kewajiban Pajak pada PT Synergy Indonesia Program Studi Akuntansi. Jurnal Akuntansi, Ekon. dan Manaj. Bisnis, 1(2), pp. 167-174.

[25].Wulandari, Diyah Puji. 2014. Sistem Informasi Manajemen Aset Pada Kantor Kecamatan Gubug Kabupaten Gorbogan Berbasis Client Server. Jurnal Teknologi Informasi dan Komputer. 